\title{
EFFECT OF VARIATIONS OF BETA VULGARIS EXTRACTS ON MASKING THE BITTER TASTE OF MOMORDICA CHARANTIA EXTRACT SYRUP
}

\author{
SUTRIYO*, RADITYA ISWANDANA, ELISA NUR WIDIYA \\ Laboratory of Pharmaceutics and Pharmaceutical Technology Development, Faculty of Pharmacy, Universitas Indonesia, Depok 16424, \\ Indonesia. Email: sutriyo@farmasi.ui.ac.id
}

Received: 24 April 2018, Revised: 26 September 2018, Accepted: 06 November 2018

\section{ABSTRACT}

Objective: This study aimed to obtain a formula with an optimal sweetener concentration of beet extract that can cover the bitter taste of bitter melon and confer optimal physical properties on the syrup.

Methods: The syrups were prepared by mixing bitter melon extract, sucrose, beet extract, sorbitol, sodium benzoate, strawberry essence, and demineralized water. The control formula and formulas 1,2 , and 3 contained beet extract at concentrations of $0 \%$ and $10 \%, 15 \%$, and $20 \%$, respectively. All formulas were evaluated to determine their physical properties, stability, and bitterness. The bitterness was tested on 30 respondents, with data being analyzed using Wilcoxon's test on SPSS software.

Results and Conclusion: Formula 3 with $20 \%$ beet extract was identified as the best formula for masking bitter taste because it had a significantly better average value than the other formulas $(\mathrm{p}<0.05)$ and the highest bitterless taste percentage $(86.67 \%)$, with physical properties of a brownishblack color, odor of mixture of strawberry and dominant beet, a sweet and dominant beet taste, pH 5.46, and specific gravity of $1.228 \mathrm{~g} / \mathrm{mL}$.

Keywords: Momordica charantia L., Bitter melon, Formulation of syrup preparation, Beta vulgaris.

(C) 2018 The Authors. Published by Innovare Academic Sciences Pvt Ltd. This is an open access article under the CC BY license (http://creativecommons. org/licenses/by/4. 0/) DOI: http://dx.doi.org/10.22159/ijap.2018.v10s1.34

\section{INTRODUCTION}

Bitter melon (Momordica charantia L.), a medicinal plant, is commonly used in Indonesia. It grows well in this country because it is suited to growth in the tropics, either wild or planted. It is commonly used as a food complement and has various health benefits. It contains charantins (steroidal glycosides) having hypoglycemic effects for the treatment of diabetes, catechins having antioxidant activity, cucurbitanes (triterpene glycosides) having inhibitory effects on Epstein-Barr virus, and sesquiterpenes having antimicrobial activity [1]

As a medicinal plant, bitter melon is still typically used in line with traditional practices by boiling or the production of juice. To increase the practicality of using bitter melon as a medicine without reducing its stability, it needs to be prepared in dosage forms. One of these options is a liquid dosage form, such as bitter melon extract syrup [2].

Another problem with bitter melon is its bitter taste, which is due to the presence of the bitter compound momordicin (a triterpenoid compound and derivative of cucurbitane) [3]. The bitterness is generally unpleasant for most people's palates, but it can be overcome by masking it using the addition of a sweetener in a formulation of bitter melon extract syrup. The sweetener used in this research was beet extract. On the basis of data from the US Department of Agriculture (2014), $100 \mathrm{~g}$ beet contains $6.76 \mathrm{~g}$ sugar [4], which is expected to be sufficient to mask the bitterness of bitter melon extract.

The background above prompted this research on formulations of bitter melon syrup extracts ( $M$. charantia $L$.) with various sweetener concentrations of beet (Beta vulgaris) to cover the bitter melon taste; the aim was to obtain a formula with an optimal sweetener concentration of beet extract that can cover the bitter taste of bitter melon and confer optimal physical properties on the syrup.

\section{MATERIALS AND METHODS}

\section{Materials}

The tools used in this study were pH meters (Hanna Instruments, USA), an oven (Memmert, Germany), analytical scales (Adam, USA), a $10 \mathrm{~mL}$ pycnometer (Pyrex, USA), a refrigerator (Toshiba, Japan), a hot plate (IKA, Germany), a homogenizer (IKA, Germany), and glassware for analysis (Schott Duran, Germany). The materials used in this research were sucrose (Angel Products, Indonesia), beet extract (Indonesian Spice and Medicinal Research Institute), bitter melon extract, sorbitol (Brataco, Indonesia), sodium benzoate (Brataco, Indonesia), strawberry flavor (Symrise, Germany), and aquadest (Brataco, Indonesia).

\section{Formulation of bitter melon extract syrup}

This research included four formulations of melon extract syrup with one formulation as a control. The formulations differed from each other in terms of the concentration of sweetener used. The composition of each formula is shown in Table 1.

First, bitter melon extract syrups were prepared using the abovementioned tools and constituents. All constituents were weighed with analytical scales. Sucrose was put into a glass beaker, dissolved in aquadest over a hot plate $\left(30^{\circ} \mathrm{C}-40^{\circ} \mathrm{C}\right)$, and then stirred using a homogenizer until reaching homogeneity. The bitter melon extract was dissolved in aquadest in a glass beaker, followed by stirring using a stirring bar until reaching homogeneity. The solution was introduced into the previous solution and then dissolved until reaching homogeneity. Sodium benzoate was dissolved in aquadest in a glass beaker and then stirred using a stirring bar until reaching homogeneity. The solution was introduced into the previous solution and then dissolved until reaching homogeneity. Sorbitol was added to the solution and then stirred until reaching homogeneity. The beet extract was dissolved in aquadest in a glass beaker using a homogenizer until reaching homogeneity and then put into the previous solution and mixed until reaching homogeneity. A strawberry flavor was added to the solution, followed by stirring until reaching homogeneity. Aquadest 
Table 1: Formulas of bitter melon extract syrups

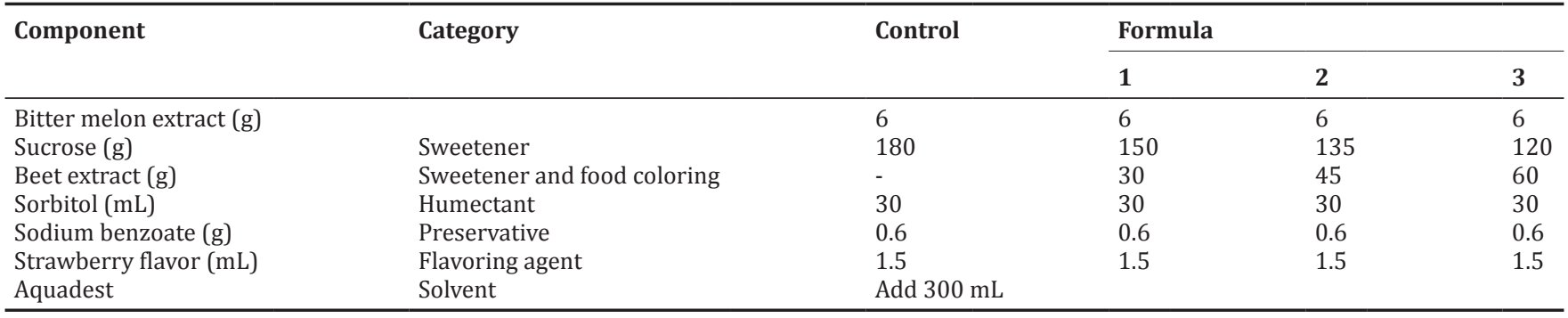

was also added until the desired volume of syrup was obtained, followed by stirring until reaching homogeneity. The syrup was stored in a container pack.

\section{Evaluation of bitter melon extract syrup}

\section{Organoleptic evaluation}

The organoleptic evaluation was performed with the aim of proving the esthetic value of the dosage forms before distribution to consumers, as well as to give reliable information to consumers that the product is feasible. Parameters assessed included the physical appearance, color, smell, and taste of the syrup [5].

\section{Determination of specific gravity}

Determination of the specific gravity was performed using the pycnometer. The procedure for calculating the specific gravity was based on the Pharmacopoeia Indonesia Edition V [6]. First, the pycnometer was cleaned, dried, and calibrated by determining its weight and water weight at $25^{\circ} \mathrm{C}$. The test substance was inserted into the pycnometer at $25^{\circ} \mathrm{C}$. The excess of the test substance was removed and weighed. The weight of the empty pycnometer was subtracted from the weight of the pycnometer that had been filled. The weight of the type was obtained by dividing the weight of the substance by the weight of water in the pycnometer. The weight of the type was calculated by dividing pcynometer weight contains a tested substance - empty weight of pycnometer with pcynometer weight contains aquadest - empty weight of pycnometer.

\section{pH determination}

The $\mathrm{pH}$ test was performed using a $\mathrm{pH}$ meter at room temperature. The electrode was calibrated with standard buffers of $\mathrm{pH} 4$ and 7 , and the electrode was immersed in a syrup dosage form until the $\mathrm{pH}$ value appeared on the screen. The $\mathrm{pH}$ results were recorded [6].

\section{Physical stability test}

Physical stability tests were performed at low temperature $\left(4^{\circ} \mathrm{C} \pm 2^{\circ} \mathrm{C}\right)$, room temperature $\left(29^{\circ} \mathrm{C} \pm 2^{\circ} \mathrm{C}\right)$, and high temperature $\left(40^{\circ} \mathrm{C} \pm 2^{\circ} \mathrm{C}\right)$. All syrup formulations were stored at all three temperatures for 6 weeks, after which organoleptic observations (discoloration, odor, and homogeneity) and $\mathrm{pH}$ measurements were performed. In a cycling test, the dosage forms were stored at a cold temperature $\pm 4^{\circ} \mathrm{C}$ for $24 \mathrm{~h}$ and then removed and placed at a temperature of $\pm 40^{\circ} \mathrm{C}$ for $24 \mathrm{~h}$ (one cycle). This experiment was repeated as many as 6 times, and then, observations and evaluations were performed for comparison with previous dosage forms $[7,8]$.

\section{Test of bitterness}

A bitter taste test was performed on 30 respondents meeting the criteria of having no oral disorders such as canker sores, bleeding gums, and toothache and not having consumed hot or bitter food or beverages within the past $6 \mathrm{~h}$. Respondents were aged from 18 to 40 years old and included both men and women. Random codes were used to identify each sample of syrup formulation and one standard for the analyses of the bitterness of bitter melon solution, to ensure that the researchers and respondents were in a blinded state (double-blind setup). The standard bitter taste was made by dissolving the Momordica charantia extract in the aquadest with the same extract concentration in the dosage formulas. Respondents were asked to assess the bitter taste of each preparation using the following scoring categories: 5 (very bitter), 4 (bitter), 3 (quite bitter), 2 (slightly bitter), and 1 (not bitter) [9].

After obtaining bitter taste test data from the 30 respondents, the processing of the data was performed by making the percentage of spread value of each formula, with statistical analysis being performed using SPSS software. A normality test was used to determine whether the data were normally distributed. The statistical test performed was a non-parametric statistical test, namely Wilcoxon's test, to determine whether there was a significant difference in the means between standard solutions of bitter melon extract with each syrup dosage formula. The next statistical test was the Mann-Whitney U-test to determine whether there was a significant difference in the means between each dosage sample. Furthermore, to determine whether there was a significant difference in the mean variation of beet extract concentration in the bitter taste testing of all formulas, a non-parametric test, namely Kruskal-Wallis test, was performed.

\section{RESULTS AND DISCUSSION}

\section{Organoleptic evaluation}

The results of organoleptic evaluation of each syrup formula are shown in Table 2.

The obtained results indicated that the beet extract concentration used in the dosage form of syrup affected each organoleptic parameter. The greater the concentration of extract of beet used, the darker the color of the dosage form. Moreover, the smell and taste were also increasingly dominated by the extract of the beet itself with a greater concentration of beet extract used, with the smell and taste of beet extract being more dominant in the dosage form of syrup.

\section{Determination of specific gravity}

The results of the specific gravity obtained were as follows: Control formula $(1.282 \mathrm{~g} / \mathrm{mL})$, formula $1(1.271 \mathrm{~g} / \mathrm{mL})$, formula $2(1.259 \mathrm{~g} / \mathrm{mL})$, and formula $3(1.228 \mathrm{~g} / \mathrm{mL})$. The weights thus decreased in order from the control formula to formula 3. A relationship between the sweetener concentration and the specific gravity was identified. The sucrose concentration influences the specific gravity of the dosage, with a lower sucrose concentration giving a smaller type weight value, so it can be seen that the sucrose concentration plays a role in adding the type weight to the syrup.

\section{pH determination}

The $\mathrm{pH}$ results obtained were as follows: Control formula (5.10), formula 1 (5.41), formula 2 (5.45), and formula 3 (5.46). These results show that increasing the beet extract concentration had an effect of increasing the $\mathrm{pH}$ of syrup. These results also show that the $\mathrm{pH}$ of the syrup is still in the range of $\mathrm{pH}$ values of syrup available on the market, namely between $\mathrm{pH} 4$ and 7 [7,8,10].

\section{Physical stability test}

The results of the low-temperature physical stability test are shown in Table 3. 
Table 2: Organoleptic evaluation results of bitter melon extract syrup

\begin{tabular}{lllll}
\hline Parameter & Formula & & & \\
\cline { 2 - 5 } & Control & $\mathbf{1}$ & $\mathbf{2}$ & $\mathbf{3}$ \\
\hline Color & Brownish-orange & Brownish-black & Brownish-black & Brownish-black \\
Standard of color & OS/LP 422 deep yellow & FG 77 brown & FG 77 brown & FG 77 brown \\
Smell & Strawberry flavor & Strawberry flavor and a little beet & Strawberry flavor and beet & Strawberry flavor and dominant beet \\
Taste & Sweet & Sweet and a little beet & Sweet and a little beet & Sweet and dominant beet \\
\hline
\end{tabular}

Table 3: Result of physical stability test at low temperature $\left(4^{\circ} \mathrm{C}\right)$

\begin{tabular}{|c|c|c|c|c|c|c|}
\hline \multirow[t]{2}{*}{ Dosage form } & \multirow[t]{2}{*}{ In week } & \multicolumn{5}{|l|}{ Observation } \\
\hline & & Color & Smell & Taste & Homogeneity & pH \\
\hline \multirow[t]{6}{*}{ Control formula } & 0 & Brownish-orange & Strawberry flavor & Sweet & Homogeneous & 5.10 \\
\hline & 2 & $(-)$ & $(-)$ & $(-)$ & Homogeneous & 5.22 \\
\hline & 3 & $(-)$ & $(-)$ & $(-)$ & Homogeneous & 5.12 \\
\hline & 4 & $(-)$ & Slightly reduced & Slightly reduced & Homogeneous & 5.12 \\
\hline & 5 & $(-)$ & Slightly reduced & Equal to that at 4 weeks & Homogeneous & 5.12 \\
\hline & 6 & $(-)$ & Equal to that at 5 weeks & Slightly reduced & Homogeneous & 5.10 \\
\hline \multirow[t]{7}{*}{ Formula 1} & 0 & Brownish-black & Strawberry flavor and a little beet & Sweet and a little beet & Homogeneous & 5.41 \\
\hline & 1 & $(-)$ & $(-)$ & $(-)$ & Homogeneous & 5.44 \\
\hline & 2 & $(-)$ & $(-)$ & $(-)$ & Homogeneous & 5.48 \\
\hline & 3 & $(-)$ & Beet smell reduced & Slightly reduced & Homogeneous & 5.50 \\
\hline & 4 & $(-)$ & A bit of flavor and beet & Slightly reduced & Homogeneous & 5.43 \\
\hline & 5 & $(-)$ & Beet smell and flavor reduced & Equal to that at 4 weeks & Homogeneous & 5.42 \\
\hline & 6 & $(-)$ & Equal to that at 5 weeks & Slightly reduced & Homogeneous & 5.40 \\
\hline \multirow[t]{6}{*}{ Formula 2} & 0 & Brownish-black & Strawberry flavor and beet & Sweet and a little beet & Homogeneous & 5.45 \\
\hline & 2 & $(-)$ & Beet smell reduced & Slightly reduced & Homogeneous & 5.49 \\
\hline & 3 & $(-)$ & Equal to that at 2 weeks & Equal to that at 2 weeks & Homogeneous & 5.55 \\
\hline & 4 & $(-)$ & Beet smell reduced & Slightly reduced & Homogeneous & 5.34 \\
\hline & 5 & $(-)$ & Beet smell and flavor reduced & Slightly reduced & Homogeneous & 5.30 \\
\hline & 6 & $(-)$ & Equal to that at 5 weeks & Equal to that at 5 weeks & Homogeneous & 5.28 \\
\hline \multirow[t]{7}{*}{ Formula 3} & 0 & Brownish-black & Strawberry flavor and dominant beet & Sweet and dominant beet & Homogeneous & 5.46 \\
\hline & 1 & $(-)$ & $(-)$ & $(-)$ & Homogeneous & 5.48 \\
\hline & 2 & $(-)$ & Beet smell reduced & Slightly reduced & Homogeneous & 5.57 \\
\hline & 3 & $(-)$ & Beet smell reduced & Equal to that at 2 weeks & Homogeneous & 5.62 \\
\hline & 4 & $(-)$ & Equal to that at 3 weeks & Slightly reduced & Homogeneous & 5.44 \\
\hline & 5 & $(-)$ & Beet smell reduced & Equal to that at 4 weeks & Homogeneous & 5.38 \\
\hline & 6 & $(-)$ & Equal to that at 5 weeks & Equal to that at 5 weeks & Homogeneous & 5.36 \\
\hline
\end{tabular}

Annotation: (-) Indicates no changes occurred

The obtained results indicate that no changes in color and homogeneity of the four dosages occurred. The smell and taste of beet in the dosage form tested at low temperatures decreased almost every week, so it can be said that the storage of the dosage at low temperature reduces the odor and taste of beet extract present in the dosage form. In the cooling process, just like food stored in a refrigerator, low temperatures can reduce or mask the odor and taste of preparation [11]. The obtained cold effects provide the first sensation when doing inspection of smell or taste so that the original smell and taste will appear shortly after the examination [12]. Furthermore, the $\mathrm{pH}$ measurement results are shown in Table 3. The $\mathrm{pH}$ changes that occurred during this low-temperature physical stability test may have been due to the occurrence of certain chemical reactions in the dosage form that affected the particular content; to clarify this, further chemical evaluations such as assays are needed [13].

The results of the physical temperature stability test are shown in Table 4. The results indicate that there is no change in the color, smell, taste, or homogeneity of the four dosages. This shows that each of the syrup dosage formulas is stable at room temperature, which is due to the manufacturing process being carried out at room temperature and the constituents contained in the syrup dosage form also being more stable at room temperature. Furthermore, from the results of $\mathrm{pH}$ measurement performed at room temperature as shown in Table 4, $\mathrm{pH}$ initially tends to be stable but begins to decrease at week 4 . The decrease may occur because of the possibility of the growth of certain microbes in the preparation causing a decrease in $\mathrm{pH}$, but this must be proven by microbial testing [13-15].

On the basis of the results obtained from the stability test performed at high temperature as shown in Table 5, it can be concluded that there is no change in color and homogeneity of the four dosages. The smell and taste of beets in the dosage form tested at a high temperature increased almost every week, so it can be asserted that the storage of dosages at a high temperature can increase the smell and taste of beet contained in the dosage form. This may have occurred because the substances that play a role in the emergence of the taste and smell of beet evaporated at high temperatures [16]. The results of $\mathrm{pH}$ measurement are shown in Table 5. A rise of $\mathrm{pH}$ occurred until week 3 , followed by a decline beginning at week 4 . The $\mathrm{pH}$ changes that occurred during this high-temperature stability test may have occurred because of certain chemical reactions in the dosage form affecting the particular composition. The composition may affect the $\mathrm{pH}$ change. To determine particular thing, further chemical evaluation such as level determination should be performed [13]. Another possibility is the growth of certain microbes in the dosage form that causes the $\mathrm{pH}$ to decrease; however, this must be proven by microbial testing [15].

The results of the stability test with cycling as shown in Table 6 indicate that there were no changes in color, smell, or homogeneity of the four 
Table 4: Results of physical stability test at room temperature $\left(29^{\circ} \mathrm{C}\right)$

\begin{tabular}{|c|c|c|c|c|c|c|}
\hline \multirow[t]{2}{*}{ Dosage form } & \multirow[t]{2}{*}{ In week } & \multicolumn{5}{|l|}{ Observation } \\
\hline & & Color & Smell & Taste & Homogeneity & $\mathbf{p H}$ \\
\hline \multirow[t]{6}{*}{ Control formula } & 0 & Brownish-orange & Strawberry flavor & Sweet & Homogeneous & 5.0 \\
\hline & 2 & $(-)$ & $(-)$ & $(-)$ & Homogeneous & 5.10 \\
\hline & 3 & $(-)$ & $(-)$ & $(-)$ & Homogeneous & 5.10 \\
\hline & 4 & $(-)$ & $(-)$ & $(-)$ & Homogeneous & 5.04 \\
\hline & 5 & $(-)$ & $(-)$ & $(-)$ & Homogeneous & 5.04 \\
\hline & 6 & $(-)$ & $(-)$ & $(-)$ & Homogeneous & 5.02 \\
\hline \multirow[t]{7}{*}{ Formula 1} & 0 & Brownish-black & Strawberry flavor and a little Beet & Sweet and a little beet & Homogeneous & 5.41 \\
\hline & 1 & $(-)$ & $(-)$ & $(-)$ & Homogeneous & 5.41 \\
\hline & 2 & $(-)$ & $(-)$ & $(-)$ & Homogeneous & 5.42 \\
\hline & 3 & $(-)$ & $(-)$ & $(-)$ & Homogeneous & 5.42 \\
\hline & 4 & $(-)$ & $(-)$ & $(-)$ & Homogeneous & 5.30 \\
\hline & 5 & $(-)$ & $(-)$ & $(-)$ & Homogeneous & 5.30 \\
\hline & 6 & $(-)$ & $(-)$ & $(-)$ & Homogeneous & 5.30 \\
\hline \multirow{6}{*}{ Formula 2} & 0 & Brownish-black & Strawberry flavor and beet & Sweet and a little beet & Homogeneous & 5.45 \\
\hline & 2 & $(-)$ & $(-)$ & $(-)$ & Homogeneous & 5.46 \\
\hline & 3 & $(-)$ & $(-)$ & $(-)$ & Homogeneous & 5.44 \\
\hline & 4 & $(-)$ & $(-)$ & $(-)$ & Homogeneous & 5.33 \\
\hline & 5 & $(-)$ & $(-)$ & $(-)$ & Homogeneous & 5.32 \\
\hline & 6 & $(-)$ & $(-)$ & $(-)$ & Homogeneous & 5.32 \\
\hline \multirow[t]{7}{*}{ Formula 3} & 0 & Brownish-black & Strawberry flavor and dominant beet & Sweet and dominant beet & Homogeneous & 5.46 \\
\hline & 1 & $(-)$ & $(-)$ & $(-)$ & Homogeneous & 5.46 \\
\hline & 2 & $(-)$ & $(-)$ & $(-)$ & Homogeneous & 5.46 \\
\hline & 3 & $(-)$ & $(-)$ & $(-)$ & Homogeneous & 5.46 \\
\hline & 4 & $(-)$ & $(-)$ & $(-)$ & Homogeneous & 5.40 \\
\hline & 5 & $(-)$ & $(-)$ & $(-)$ & Homogeneous & 5.40 \\
\hline & 6 & $(-)$ & $(-)$ & $(-)$ & Homogeneous & 5.40 \\
\hline
\end{tabular}

Annotation: (-) Indicates no changes occur

Table 5: Results of physical stability testing at high temperature (40 C)

\begin{tabular}{|c|c|c|c|c|c|c|}
\hline \multirow[t]{2}{*}{ Dosage form } & \multirow{2}{*}{$\begin{array}{l}\text { Week } \\
\text { number }\end{array}$} & \multicolumn{5}{|l|}{ Observation } \\
\hline & & Color & Smell & Taste & Homogeneity & pH \\
\hline \multirow[t]{7}{*}{ Control formula } & 0 & Brownish-orange & Strawberry flavor & Sweet & Homogeneous & 5.10 \\
\hline & 1 & $(-)$ & $(-)$ & $(-)$ & Homogeneous & 5.16 \\
\hline & 2 & $(-)$ & $(-)$ & $(-)$ & Homogeneous & 5.23 \\
\hline & 3 & $(-)$ & $(-)$ & $(-)$ & Homogeneous & 5.25 \\
\hline & 4 & $(-)$ & $\begin{array}{l}\text { A slight smell of bitter melon } \\
\text { emerges }\end{array}$ & $\begin{array}{l}\text { A slight taste of bitter melon } \\
\text { emerges }\end{array}$ & Homogeneous & 5.19 \\
\hline & 5 & $(-)$ & Similar to week 4 & Similar to week 4 & Homogeneous & 5.12 \\
\hline & 6 & $(-)$ & Similar to week 4 & Similar to week 4 & Homogeneous & 5.10 \\
\hline \multirow[t]{6}{*}{ Formula 1} & 0 & Brownish-black & Strawberry flavor and slight beet & Sweet and slight beet & Homogeneous & 5.41 \\
\hline & 1 & $(-)$ & $(-)$ & $(-)$ & Homogeneous & 5.42 \\
\hline & 2 & $(-)$ & $(-)$ & $(-)$ & Homogeneous & 5.44 \\
\hline & 3 & $(-)$ & $(-)$ & $(-)$ & Homogeneous & 5.54 \\
\hline & 4 & $(-)$ & Slightly stronger & Taste of beet slightly increases & Homogeneous & 5.30 \\
\hline & 5 & $(-)$ & Similar to week 4 & Similar to week 4 & Homogeneous & 5.28 \\
\hline \multirow{6}{*}{ Formula 2} & 1 & $(-)$ & $(-)$ & $(-)$ & Homogeneous & 5.46 \\
\hline & 2 & $(-)$ & Slightly stronger & $(-)$ & Homogeneous & 5.48 \\
\hline & 3 & $(-)$ & Smell of beet gets stronger & Taste of beet slightly increases & Homogeneous & 5.54 \\
\hline & 4 & $(-)$ & Smell of beet quite strong & Taste of beet slightly increases & Homogeneous & 5.33 \\
\hline & 5 & $(-)$ & Similar to week 4 & Similar to week 4 & Homogeneous & 5.30 \\
\hline & 6 & $(-)$ & Smell of beet gets stronger & Taste of beet increases & Homogeneous & 5.26 \\
\hline \multirow[t]{7}{*}{ Formula 3} & 0 & Brownish-black & $\begin{array}{l}\text { Strawberry flavor and dominant } \\
\text { beet }\end{array}$ & Sweet and dominant beet & Homogeneous & 5.46 \\
\hline & 1 & $(-)$ & $(-)$ & $(-)$ & Homogeneous & 5.50 \\
\hline & 2 & $(-)$ & Slightly stronger & Taste of beet slightly increases & Homogeneous & 5.57 \\
\hline & 3 & $(-)$ & Smell of beet quite strong & Taste of beet slightly increases & Homogeneous & 5.58 \\
\hline & 4 & $(-)$ & Similar to week 3 & Similar to week 3 & Homogeneous & 5.43 \\
\hline & 5 & $(-)$ & Similar to week 3 & Similar to week 3 & Homogeneous & 5.42 \\
\hline & 6 & $(-)$ & Strong smell of beet & Taste of beet is quite strong & Homogeneous & 5.38 \\
\hline
\end{tabular}

Annotation: (-) Indicates no changes occur 
Table 6: Results of physical stability cycling test

\begin{tabular}{|c|c|c|c|c|c|c|}
\hline \multirow{2}{*}{$\begin{array}{l}\text { Dosage } \\
\text { form }\end{array}$} & \multirow{2}{*}{$\begin{array}{l}\text { Cycle } \\
\text { number }\end{array}$} & \multicolumn{5}{|l|}{ Observation } \\
\hline & & Color & Smell & Taste & Homogeneity & pH \\
\hline \multirow[t]{2}{*}{ Control } & 0 & Brownish-orange & Strawberry flavor & Sweet & Homogeneous & 5.10 \\
\hline & 6 & $(-)$ & $(-)$ & Slight bitter taste emerges & Homogeneous & 4.46 \\
\hline \multirow[t]{2}{*}{ Formula 1} & 0 & Brownish-black & Strawberry flavor and slight beet & Sweet and slight beet & Homogeneous & 5.41 \\
\hline & 6 & $(-)$ & $(-)$ & Taste of bit increases & Homogeneous & 4.63 \\
\hline \multirow[t]{2}{*}{ Formula 2} & 0 & Brownish-black & Strawberry flavor and beet & Sweet and slight beet & Homogeneous & 5.45 \\
\hline & 6 & $(-)$ & $(-)$ & Taste of beet increases & Homogeneous & 4.79 \\
\hline \multirow[t]{2}{*}{ Formula 3} & 0 & Brownish-black & Strawberry flavor and dominant beet & Sweet and dominant beet & Homogeneous & 5.46 \\
\hline & 6 & $(-)$ & $(-)$ & Taste of beet increases & Homogeneous & 4.89 \\
\hline
\end{tabular}

Annotation: (-) Indicates no changes occur

dosages. However, there were changes in the taste of the dosage form, with formulas 1, 2, and 3 being associated with increases in the taste of beets. This decreased the sweet taste of the dosage formulas, while in the control formula, slight bitterness of the bitter melon extract emerged. Furthermore, regarding the results of $\mathrm{pH}$ measurement, a decrease in $\mathrm{pH}$ of the four dosage formulas was observed, with an average decrease of 0.66 . The substantial $\mathrm{pH}$ changes occurring during the cycling stability test showed that changing temperatures can lower the $\mathrm{pH}$ of the dosage form. This can occur because of certain chemical reactions in the dosage that affects a particular composition; the speed of the chemical reaction itself is affected by the temperature. This chemical reaction can affect the $\mathrm{pH}$ change, but clarification of this issue in the current context requires further chemical evaluations such as assays [13].

\section{Bitter taste test}

Bitter taste test data were obtained from 30 respondents who completed the bitter taste test questionnaire. The percentage of distribution results from the bitter taste test toward the standard bitter taste and the four other formulas is shown in Table 7.

The results obtained from bitter taste test revealed that, for the bitter standard, the largest proportion of respondents gave a bitter taste score of 3 (quite bitter), with a percentage of $33.33 \%$. For the control, the majority of respondents gave a bitter taste score of 1 (not bitter), with a percentage of $63.33 \%$. For formula 1, the majority of respondents gave a bitter taste score of 1 (not bitter), with a percentage of $66.67 \%$. For formula 2, the majority of respondents gave a bitter taste score of 1 (not bitter), with a percentage of $50.00 \%$. For formula 3, the majority of respondents gave a bitter taste score of 1 (not bitter), with a percentage of $86.67 \%$.

On the basis of the distribution of results from the bitter taste test, it can be seen that formula 3 is the dosage form with the least bitter taste; specifically, the percentage giving a score of 1 (not bitter) is greater than for the other dosage forms and none of the respondents gave a score of 5 (very bitter).

The data were also analyzed using SPSS software. The first data analysis involved a normality test to determine whether the data to be tested are normally distributed, specifically the Shapiro-Wilk test.

On the basis of the results obtained from the normality test as shown in Table 8 , the analyses for the five groups of samples gave $\mathrm{p}<0.05$, indicating that the bitter taste test data were not normally distributed. As such, the data processing was performed using a non-parametric test.

Wilcoxon's test is the non-parametric statistical text used here, as it should be used for non-normally distributed data. This test was used to determine whether there was a significant difference between the averages of two paired samples, just like the paired sample t-test.

On the basis of the results for the four samples, a $p<0.001$ was obtained. As this value is $<0.05$, it can be concluded that there is
Table 7: Results of distribution percentage values of bitter taste test

\begin{tabular}{llllll}
\hline \multirow{2}{*}{$\begin{array}{l}\text { Bitter parameter } \\
\text { score }\end{array}$} & \multicolumn{5}{l}{ Sample percentage (\%) } \\
\cline { 2 - 6 } & $\begin{array}{l}\text { Bitter } \\
\text { standard }\end{array}$ & Control & F1 & F2 & F3 \\
\hline Not bitter (1) & 20.00 & 63.33 & 66.67 & 50.00 & 86.67 \\
Slightly bitter (2) & 13.33 & 23.33 & 13.33 & 33.33 & 6.67 \\
Quite bitter (3) & 33.33 & 10.00 & 10.00 & 13.33 & 3.33 \\
Bitter (4) & 16.67 & 3.33 & 6.67 & 0.00 & 3.33 \\
Very bitter (5) & 16.67 & 0.00 & 3.33 & 3.33 & 0.00 \\
\hline
\end{tabular}

Table 8: Results of Shapiro-Wilk normality test

\begin{tabular}{lll}
\hline Group & $\mathbf{n}$ & p value \\
\hline Bitter standard of bitter melon extract & 30 & 0.008 \\
Control formula & 30 & $<0.001$ \\
Formula 1 & 30 & $<0.001$ \\
Formula 2 & 30 & $<0.001$ \\
Formula 3 & 30 & $<0.001$ \\
\hline
\end{tabular}

Table 9: Results of Kruskal-Wallis Test

\begin{tabular}{lllll}
\hline Group & n & Mean \pm SD & Minimum-Maximum & p value \\
\hline Control formula & 30 & $1.53 \pm 0.82$ & $1-4$ & $<0.048$ \\
Formula 1 & 30 & $1.67 \pm 1.12$ & $1-5$ & \\
Formula 2 & 30 & $1.73 \pm 0.94$ & $1-5$ & \\
Formula 3 & 30 & $1.23 \pm 0.68$ & $1-4$ & \\
\hline
\end{tabular}

SD: Standard deviation, $\mathrm{p}<0.05$ (statistically significant)

a statistically significant difference in bitterness among the four dosage formulas with a bitter taste standards using bitter melon extract solution.

To discover whether the variation of beet extract concentration had any effect on the bitter taste, the data were analyzed by the KruskalWallis test, which is a non-parametric statistical test used to analyze non-normally distributed data. This test aims to determine whether there is a statistically significant difference between two or more groups. In this study, the authors wanted to determine whether there was a difference in the average bitterness values among the four dosage forms with different beet extract concentrations: Control formula with $0 \%$ beet extract, formula 1 with $10 \%$ beet extract, formula 2 with $15 \%$ beet extract, and formula 3 with $20 \%$ beet extract.

The results of the Kruskal-Wallis test shown in Table 9 reveal a p-value (Asymp. Sig.) of 0.048; since this value is $<0.05$, it can be concluded that there is a statistically significant difference in the variation of the concentration of beet extract toward bitter taste in dosage form of bitter melon extract syrup. As such, it can be asserted 
Table 10: Results of Mann-Whitney U-test among samples for best formulation among all dosage

\begin{tabular}{lllll}
\hline \multirow{2}{*}{ Group } & \multicolumn{2}{l}{ Significance } & & \\
\cline { 2 - 5 } & Control & F1 & F2 & F3 \\
\hline Control & - & 1.000 & 0.340 & $0.049^{*}$ \\
F1 & 1.000 & - & 0.391 & 0.065 \\
F2 & 0.340 & 0.391 & - & $0.004^{*}$ \\
F3 & $0.049^{*}$ & 0.065 & $0.004^{*}$ & - \\
\hline
\end{tabular}

*Statistically significant with $\mathrm{p}<0.05$

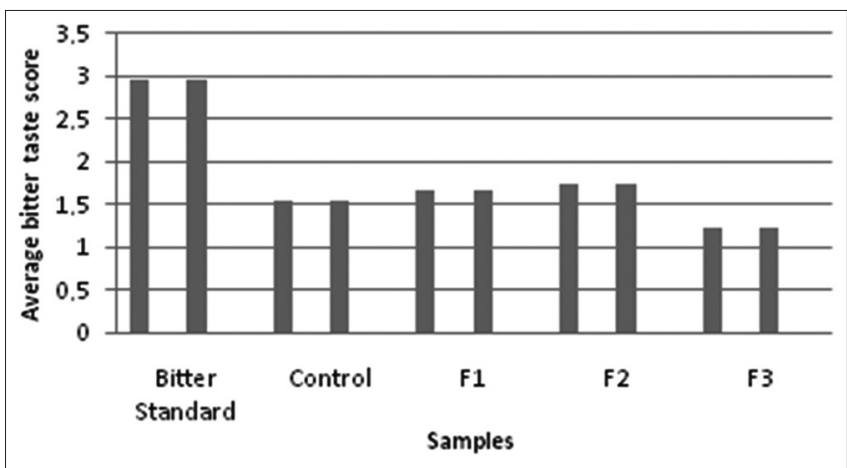

Fig. 1: Average dosage forms' bitter taste of bitter melon extract syrup

that the concentration of beet extract affects the bitter taste of the syrup dosage form.

The graph as shown in Fig. 1, based on the average bitter taste score of each preparation, suggests that the order of preparations from the least bitter to most bitter is as follows: F3, F2, F1, control, and bitter standard.

To determine the best formulation among all dosage forms, data were analyzed by the Mann-Whitney U-test to examine the significance of differences in the means among the samples.

The results of the Mann-Whitney U-test for analyzes among the dosage forms are shown in Table 10. They reveal that formula 3 has a significantly different mean from the other dosage forms, with $\mathrm{p}=0.049$, 0.065 , and 0.004 . As such, it can be concluded that the syrup of formula 3 is the best bitter melon syrup dosage form.

\section{CONCLUSION}

The results of tests performed in this study revealed that the best formula for masking the bitterness of bitter melon extract is formula 3 , which contains a concentration of sweetener extract of beets of $20 \%$. This has the physical properties of a brownish-black color, a smell featuring a mix of strawberry and dominant beet, a sweet taste dominated by beets, $\mathrm{pH} 5.46$, and weight of $1.228 \mathrm{~g} / \mathrm{mL}$. Further research regarding the stability of dosage forms should be conducted by determining the levels and microbial limit tests of each formulation.

\section{ACKNOWLEDGMENT}

The authors are grateful for the financial support for this study from the Directorate of Research and Community Engagement Universitas Indonesia through nch Grants 2017.

\section{CONFLICTS OF INTEREST}

The authors have no conficts of interest.

\section{REFERENCES}

1. Sharma S, Tandon S, Semwal B, Singh, K. Momordica charantia Linn: A comprehensive review on bitter remedy. J Pharm Res Opin 2011;1:42-7.

2. National Agency of Drug and Food Control of Republic of Indonesia. Identify some plants that people use as an antidiabetic to help lower blood sugar levels. InfoPOM 2004;5:11.

3. Gupta M, Sharma S, Gautam A, Bhadauria R. Momordica charantia Linn. (Karela): Nature's silent healer. Int J Pharm Sci Rev Res 2011;11:32.

4. United States Department of Agriculture Agricultural Research Service. Basic Report: 11080, Beets, Raw. USDA; 2014. Available from: https:// www.ndb.nal.usda.gov/ndb/foods/show $/ 2863$ ? fgcd $=\&$ manu $=\& 1$ facet $=$ $\&$ format $=\& \operatorname{count}=\& \max =50 \&$ offset $=\&$ sort $=$ default $\&$ order $=$ asc \&qlookup $=11080 \& d s$. [Last retrieved on 2016 Oct 16].

5. Kaushik A, Chauhan V, Sudha D. Formulation and evaluation of herbal cough syrup. Eur J Pharm Med Res 2016;3:517-22.

6. Indonesian Ministry of Health. Farmakope Indonesia. $5^{\text {th }}$ ed. Jakarta: Indonesian Ministry of Health; 2014. p. 1553-63.

7. Sandhyarani G, Kumar K. Development and evaluation of herbal syrup from Couroupita guianensis used as expectorant. Asian J Pharm Sci Technol 2014;4:101-3.

8. Maheshwari R, Rajagopalan R. Formulation and evaluation of paracetamol syrup made by mixed solvency concept. Sch Res Lib 2012;4:170-4

9. Anand V, Kharb V, Kataria M, Kukkar V, Choudhury P. Taste assesment trials for sensory analysis of oral pharmaceutical products. Pak J Pharm Sci 2008;21:438-50.

10. Husen R, Yamlean P, Citraningtyas G. Formulation and evaluation of Sida rhombifolia L. leaf extract syrup. Pharm J Ilmiah Farmasi 2015;4:136.

11. United States Department of Agriculture Food Safety and Inspection Service. How Temperatures Affect Food; 2017. USDA. Available from: https://www.fsis.usda.gov/shared/PDF/How Temperatures Affect Food.pdf. [Last retrieved on $2017 \mathrm{Jul}$ 06]

12. Kludt E, Okom C, Brinkmann A, Schild D. Integrating temperature with odor processing in the olfactory bulb. J Neurosci 2015;35:892.

13. Ashton J, Geary L. The Effects of Temperature on $\mathrm{pH}$ Measurement. County Clare: Technical Services Department, Reagecon Diagnostics Ltd; 2006. p. 1-7. Retrieved from: https://www.reagecon.com/pdf/ technical papers/Effects of_Temperature_on_pH v4-_TSP-01-2.pdf.

14. Sudam N, Manish B, Ritesh M, Sachin P, Ratnaparkhi MP, Shilpa C. Evaluation of various natural suspending agents for its suspending behaviour using paracetamol as model drug for suspension. Asian J Pharma Clin Res 2012;5:183-6.

15. Jordan R, Jacobs S. The Effect of $\mathrm{pH}$ at Different Temperatures on the Growth of Bacterium Cofi with a Constant Food Supply. London: The Physiology Institute, University College of South Wales and Monmouthshire, Cardiff, and the Bacteriological Laboratory, Imperial College of Science and Technology; 2010. p. 15-23.

16. Chandran J, Nisha P, Singhal R, Pandit A. Degradation of color in beetroot (Beta vulgaris L.): A kinetics study. J Food Sci Tech 2014;51:2678-84. 